International Journal of Current Advanced Research

ISSN: O: 2319-6475, ISSN: P: 2319 - 6505, Impact Factor: SJIF: 5.995

Available Online at www.journalijcar.org

Volume 6; Issue 3; March 2017; Page No. 2822-2825

DOI: http://dx.doi.org/10.24327/ijcar.2017.2825.0116

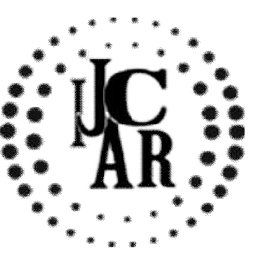

Research Article

\title{
INCIDENCE OF PHYSIOLOGICAL GOITRE AMONG STUDENTS AGED 17-25 YEARSA QUESTIONNAIRE BASED STUDY
}

\author{
*Nashwah Hinaz
}

Saveetha Dental College Saveetha University, Chennai-600007

\section{A R T I C L E I N F O}

\section{Article History:}

Received $19^{\text {th }}$ December, 2016

Received in revised form $25^{\text {th }}$ January, 2017

Accepted $15^{\text {th }}$ February, 2017

Published online $28^{\text {th }}$ March, 2017

\section{Key words:}

Physiological Goitre; Thyroid gland; swelling

\begin{abstract}
A B S T R A C T
Aim : To identify whether young adults aged 17-25 years have signs of physiological goitre.

Objective : To identify the incidences of goitre and its effects among the young adults. Background: Physiological goitre presents as a uniform, smooth, painless swelling of the thyroid gland, mainly in girls and women between 17 and 25 especially during menstruation and pregnancy. It appears to be about equally common everywhere

Reasons :Physiological goitre is harmless but it can lead to thyroid disfunction later in life. Hence awareness and knowledge about the same is necessary. Therefore the survey helps to assess the issue.
\end{abstract}

Copyright $₫ 2017$ Nashwah Hinaz. This is an open access article distributed under the Creative Commons Attribution License, which permits unrestricted use, distribution, and reproduction in any medium, provided the original work is properly cited.

\section{INTRODUCTION}

A simple goitre can occur without a known reason. It can occur when the thyroid gland is not able to make enough thyroid hormone to meet the body's needs. This can be due to, for example, a lack of iodine in a person's diet. To make up for the shortage of thyroid hormone, the thyroid gland grows larger. All forms of thyroid disorders like nontoxic goitre, Graves' disease, Hashimoto's thyroiditis and thyroid neoplasm are more common in females than males ${ }^{1}$.Puberty is a crucial period of hormonal interactions and tissue growth in the human life cycle ${ }^{2}$. Marked changes in thyroid function occur during puberty as an adaptation to body and sexual development. Thyroid disorders can adversely affect somatic and sexual growth and development during puberty ${ }^{3}$. This could be the reasonwhy disorders affecting the thyroid gland are common in adolescents ${ }^{4}$. It usually regresses, but occasionally it may persist, enlarge and become nodular depending on many factors like sex, family history, iodine intake and thyroid autoimmunity.

Thyroid disorders in adolescents may present as goitre, a nodule or a general cluster of abnormal symptoms and physical findings. The etiology and clinical presentation of thyroid disorders in adolescents substantially differ from that in adults ${ }^{5}$.Female adolescents need special care as thyroid hormones play their role in the cellular metabolism, growth

*Corresponding author: Nashwah Hinaz

Saveetha Dental College Saveetha University, Chennai600007 and development. Thyroid nodules, although common in general population $(5-7 \%)^{6}$, but less so in children or adolescents ${ }^{7,8}$. Iodine deficiency (ID) has multiple adverse effects on the growth and development in animals and humans.They result from inadequate thyroid hormone production, due to lack of sufficient iodine intake 9 . If physiological iodine requirements are not met, abnormalities of thyroid development and function may occur. Following studies, ${ }^{10,11}$ it was hypothesised that iodine deficiency may be increasing and causing goitre in urban populations ${ }^{12,13}$.

\section{METHODS AND MATERIALS}

Females aged 18-25 years were selected for the study. An online survey was conducted and 100young adults who had thyroid issues as well as those who did not have any such issues took part in it. Each person's history was also noted for reference purposes.

Table 1 Questionnaire

$\checkmark$ Age:

$\checkmark$ At what age did you attain puberty?

$\checkmark$ Are you married?

$\checkmark$ Have you noticed any swelling in your neck that is could be an enlarged thyroid gland?

$\checkmark$ If yes, at what age did you notice?

$\checkmark$ Is the swelling related to menstruation?

$\checkmark$ If you had been pregnant, was the swelling related to it?

$\checkmark$ Does the swelling move with swallowing?

$\checkmark$ Have you noticed any changes in your body weight? 
$\checkmark$ If yes, has your weight increased or decreased?

$\checkmark$ What is the time interval between your periods?

$\checkmark$ Did u notice any changes in the menstrual pattern?

$\checkmark$ How long does bleeding occur?

$\checkmark \quad$ Is it heavy bleeding or less?

\section{RESULTS AND DISCUSSION}

Have you noticed any swelling in your neck

that is could be an enlarged thyroid gland?

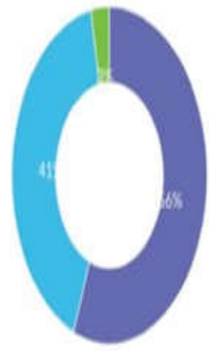

$$
\text { Chaces }
$$

Fig 1

$$
\text { If yes, has your weight increased. }
$$
or decreased?

Have u noticed altered bowel movement? or decreased?

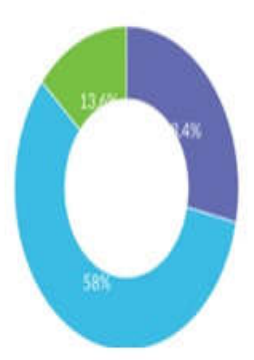

Fig 4

\section{Does the swelling move with swallowing?}

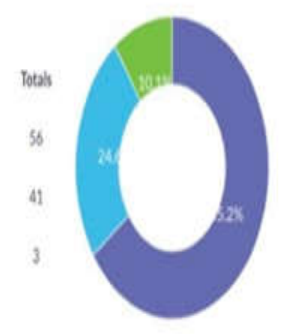

Fig 2

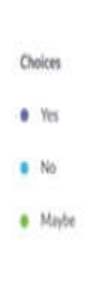

$\checkmark$ Are you having hair loss?

$\checkmark$ Do you have altered bowel movement?

$\checkmark$ If yes, is the frequency increased or decreased?

$\checkmark$ Do you have palpitations?

$\checkmark$ Do you include iodised salt in your food?

$\checkmark$ Does anyone in your family have thyroid disorders?

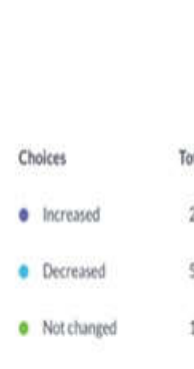

- Notchanged
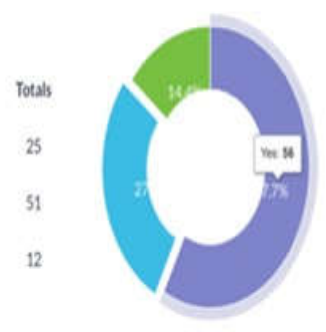

Fig 5
If yes, is the frequency increased

Or decreased?
Have you noticed any changes in your Body weight?

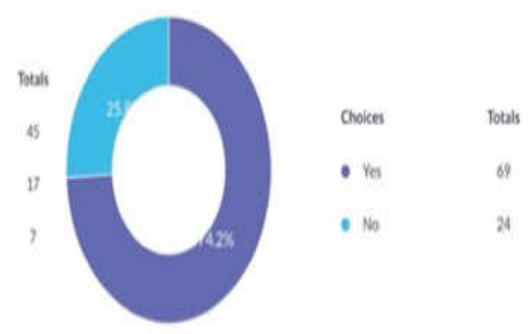

Fig 3

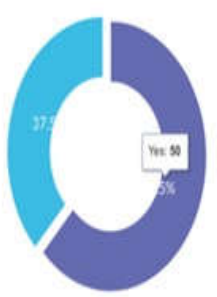

Fig 7

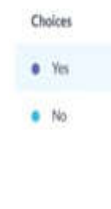

so

30

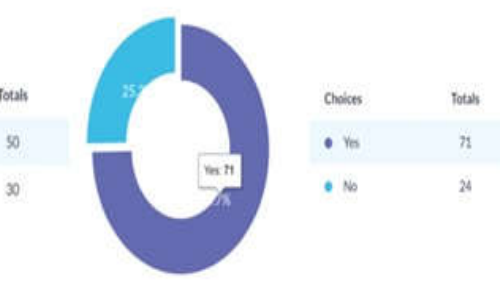

Fig 8

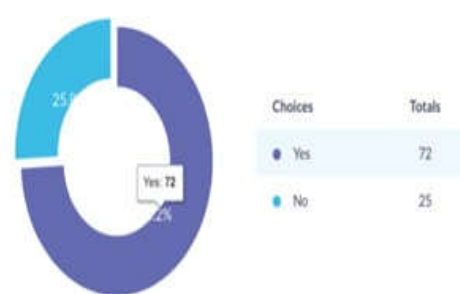

Fig 9 
100 students of the age group 17-25 years participated in the survey. $56 \%$ of young adults noticed a swelling in the neck and $41 \%$ of them did not have swelling whereas $3 \%$ were doubtful about the swelling (fig 1). Peope with thyroid disorders usually present with an enlargement of the thyroid gland (goitre), with or without symptoms of thyroid hormone deficiency or excess. In a clinic-based study from Mumbai, In women, the prevalence of goitre was higher, at $11.4 \%$, when compared with men, in whom the prevalence was $6.2 \%{ }^{14}$. When compared with the survey done online, there is a difference in the percentages as the individual attempting the survey does not have proper guidance with the diagnosis regarding goitre. $45 \%$ young adults of the $56 \%$ noticed the swelling moves with swallowing and $17 \% \%$ did not notice movement (fig 2).

In another study, goitre was present in $55.2 \%$ of students aged 10-21 years in the Kalkajee area of New Delhi and in $54.7 \%$ of students from the Chandni Chowk area of the old walled city. Goitre was more common and larger in girls ${ }^{15}$.In a study done in Belgaum district of Karnataka State, it was found that the prevalence of goitre is $24 \%$ among (20-29) years age group.Females have a higher likelihood of goiter ${ }^{16}$. Shanker $e t$ $a l$. conducted a house to house survey in Sikkim to determine the prevalence of goiter and found out that overall goiter prevalence was $54 \%$. In Goiter prevalence in males was $48.6 \%$ and in females was $59.6 \%$ and this difference was statistically significant ${ }^{17} .69 \%$ young adults noticed weight changes and $24 \%$ did not notice weight changes(fig 3).51\% young adults noticed that the weight has decreased which might be a sign of hyperthyroidism (fig 4). The prevalence of hyperthyroidism has been studied in several studies. In an epidemiological study from Cochin, subclinical and overt hyperthyroidism were present in $1.6 \%$ and $1.3 \%$ of subjects participating in a community survey ${ }^{18}$. Here also there is a vast different in the percentages calculated, this suggests that the individual has not Done proper clinical diagnosis.56\% young adultsnoticed altered bowel movement (fig 5) and $52 \%$ noticedan increase in bowel movement whichcould also be a sign of hyperthyroidism while $11 \%$ students notice decreased bowel movement (fig 6). Epidemiological studies has shown that pattern of thyroid dysfunction in a community is largely determined by iodine intake level ${ }^{19}$. But in the present age, in India, every individual consumes iodised salt, hence low iodine intake level as a reason for goitre is less prevalent. 50\% females noticed that the swelling was related to menstruation (fig 7) and almost 71\% females noticed some changes during the menstrual period (fig 8).

A total of 178 women between the age of 13 and 46 years, and who were referred to the Thyroid clinic of the KEM Hospital between January to April 1991, were included in a study that was conducted in Mumbai.All types of menstrual abnormalities were common among the female.In more than $45 \%$ of cases in the study groups (euthyroid, hypothyroid, hyperthyroid) the menstrual abnormality occurred before the onset of disease. In the remaining it started along with the disease or later. In the study theyhave observed that all types of menstrual abnormalities were significantly more frequent in women with hypo-or hyperthyroidism. Another striking feature was that in more than $45 \%$ of cases with hypo/hyperthyroidism the menstrual abnormality preceded the appearance of goitre or clinical symptoms and signs, sometimes by a period of several years ${ }^{20}$.

\section{CONCLUSION}

The study finds that Goitre is more common among women especially in the age category of 17-25 years and thus the young adults must not be ignorant towards it. The study gives us a broad information and knowledge regarding the topic. By comparing the survey conducted for these young adultswith the various other studies done on the topic, it is understood that the prevalence of goitre has increased over the years. The proper diagnosis of goitre can only be done through aclinical examination by a doctor, as an online survey cannot be completely valid. A large number of people are unaware of goitre and its related symptoms. Physiological goitre is not harmful, but knowledge regarding the same is necessary.

\section{References}

1. Rallison ML, Dobyns BM, Meikle AW, Bishop M, Lyon JL \& Stevens W. Natural history of thyroid abnor- malities: prevalence, incidence and regression of thy- roid diseases in adolescents and young adults. Am J Med 1991;91(4):363-70.

2. Hanna CE \& LaFranchi SH. Adolescent thyroid disorders. Adolesc Med 2002; 13:13-35.

3. Flueury Y, Melle GV, Woringer V, Gaillard RC \& Portmann L. Sex-dependent variations and timing of thyroid growth during puberty. $J$ Clin Endocrinol Metab 2001;86:750-4.

4. LaFranchi S. Adolescent thyroid disorders. Adolesc Med 1994; 5(1):65-86.

5. Bettendorf $\mathrm{M}$. Thyroid disorders in children from birth to adolescence. Eur J Nucl Med Mol Imaging 2002;29(Suppl 2):S439-S446.

6. Mazzaferri EL. Management of a solitary thyroid nodule. N Engl J Med 1993; 328:553-9.

7. Koutras DA. Thyroid nodules in children and adolescents: consequences in adult life. J Pediatr Endocrinol Metab 2001; 14 (Suppl 5):1283-7.

8. Hung W, Anderson KD, Chandra Rs, Kapur SP, Patterson K, Randolph JG \& August GP. Solitary thyroid nodules in 71 children and adolescents. J Pediatr Surg 1992; 27(110):1407-9.

9. Bath SC, Steer CD, Golding J, Emmett P, Rayman MP. E ect of inadequate iodine status in UK pregnant women on cognitive outcomes in their children: results from the Avon Longitudinal Studyof Parents and Children (ALSPAC). Lancet 382, 331-7, 2013.

10. McElduff A, McElduff P, Gunton JE, et al. Neonatal thyroid-stimulating hormone concentrations in Northern Sydney: further indications of mild iodine deficiency? Med J Aust 2002; 176: 317-320. <MJA full text>

11. Gunton JE, Hams G, Fiegert M, McElduff A. Iodine deficiency in ambulatory participants at a Sydney teaching hospital: is Australia truly iodine replete? Med J Aust 1999; 171: 467-470. <MJA full text>

12. Eastman CJ. The status of iodine nutrition in Australia. In: Delange F, Dunn JT, Glinoer D. Iodine deficiency in Europe -a continuing concern. New York: Plenum Press, 1993: 133-139.

13. Eastman CJ. Where has all our iodine gone? Med J Aust 1999; 171: 455-456. 
14. Desai PM. Disorders of the Thyroid Gland in India. Indian J Pediatr 1997;64:11-20

15. Endemic goitre in Delhi.Author (s) : Pandav, C. S.; Kochupillai, N.; Karmarkar, M. G.; Ramachandran, K.; GOPINATH, P. G.; Nath, L. M. Journal article : Indian Journal of Medical Research 1980 Vol.72 pp.81-87

16. Prevalence of Goiter in rural area of Belgaum district, Karnataka R Kamath ${ }^{1}$, Vinod Bhat $^{2}$, RSP $\mathrm{Rao}^{2}$, Acharya Das ${ }^{3}$, KS Ganesh ${ }^{4}$, Asha Kamath ${ }^{2}$ ${ }^{1}$ Department of Community Medicine, Melaka Medical College, Malaysia ${ }^{2}$ Department of Community Medicine, KMC, Manipal, India

${ }^{3}$ Department of Community Medicine, KS Hegde Medical College, Mangalore, Karnataka, India ${ }^{4}$ Department of Community Medicine, Kasturba Medical College, Mangalore, India
17. Sankar R, Pulger T, Gomathi S, Bimal R, Gyatso TR, Pandav CS. Epidemiologic endemic goitre in Sikkim. $J$ Assoc Pediatr I 1987;45:936-9.

18. Usha Menon V, Sundaram KR, Unnikrishnan AG, Jayakumar RV, Nair V, Kumar H. High prevalence of undetected thyroid disorders in an iodine sufficient adult south Indian population. J Indian Med Assoc 2009;107:72-7.

19. Knudsen N, Bulow I, Jorgensen T, Laurberg P, Ovesen $\mathrm{L}$ and Perrild H. Comparative study of thyroid function and types of thyroid dysfunction in two areas in Denmark with slightly different iodine status. Eur $J$ Endocrinol 2000; 143: 485-91.

20. Menstrual irregularities and lactation failure may precede thyroid dysfunction or goitre. JV Joshi, SD Bhandarkar, M Chadha, D Balaiah, R Shah Institute for Research in Reproduction, Seth GS Medical College, Parel, Bombay, Maharashtra

\section{Please cite this article in press as:}

Nashwah Hinaz (2017), Incidence Of Physiological Goitre Among Students Aged 17-25 Yearsa Questionnaire Based Study, International Journal of Current Advanced Research, 6(3), pp. 2822-2825. http://dx.doi.org/10.24327/ijcar.2017.2825.0116 